\title{
Spent Nuclear Fuels Project Characterization Data Quality Objectives Strategy
}

L. A. Lawrence

Westinghouse Hanford Company

K. S. Redus

MACTEC

T. A. Thornton

Pacific Northwest Laboratory

Date Published
December 1994

Prepared for the U.S. Department of Energy Office of Environmental Restoration and Waste Management

$\begin{array}{ll}\text { Westinghouse } & \text { P.O. Box } 1970 \\ \text { Hanford Company } & \text { Richland, Washington } 99352\end{array}$

Hantord Operations and Engineering Contractor for the

U.S. Department of Energy under Contract DE-AC06-87RL10930
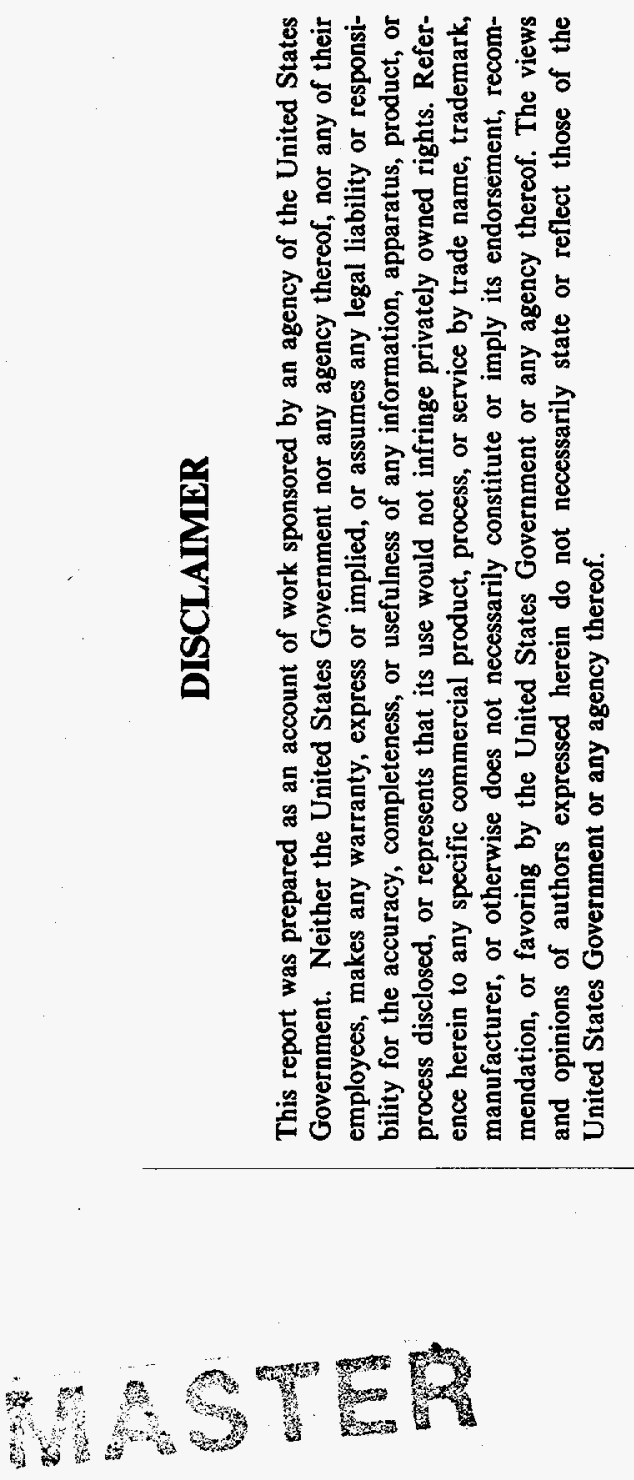


\section{DISCLAIMER}

Portions of this document may be illegible in electronic image products. Images are produced from the best available original document. 


\section{RELEASE AUTHORIZATION}

Document

Number:

Document Title: $\quad$ Spent Nuclear Fuels Project Characterization Data Quality Objectives Strategy

Release Date: $\quad$ December 12, 1994

This document was reviewed following the procedures described in WHC-CM-3-4 and is:

APPROVED FOR PUBLIC RELEASE

WHC Information Release Administration Specialist:

M. Bostor

MN Boston 
Document Title: SPENT NUCLEAR FUELS PROJECT CHARACTERIZATION DATA QUALITY OBJECTIVES STRATEGY

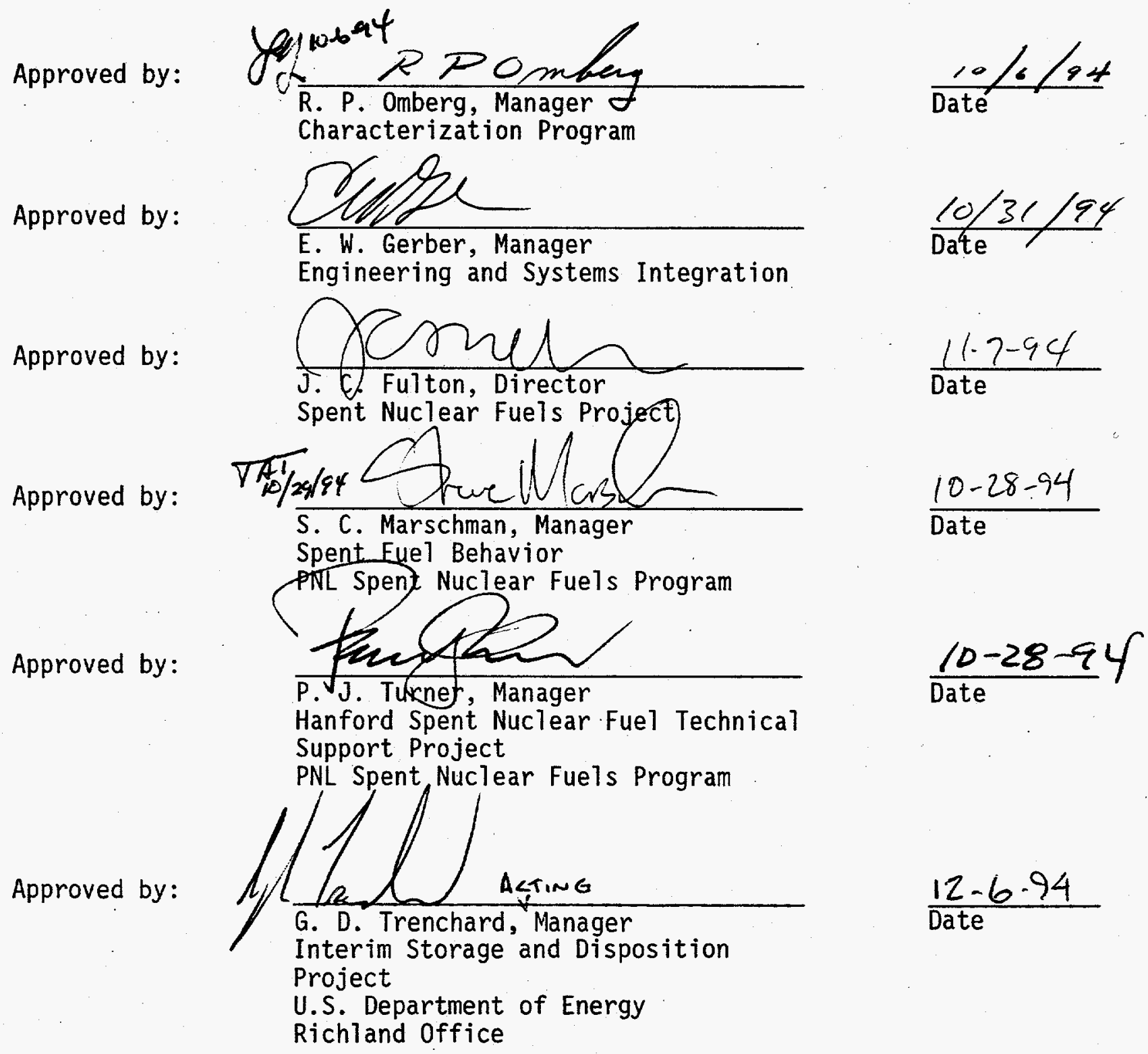


WHC-EP-0795

Rev. 0

\section{EXECUTIVE SUMMARY}

A strategy is presented for implementation of the Data Quality Objectives (DQ0) process to the Spent Nuclear Fuels Project (SNFP) characterization activities. Westinghouse Hanford Company (WHC) and the Pacific Northwest Laboratory (PNL) are teaming in the characterization of the SNF on the Hanford Site and are committed to the DQO process outlined in this strategy. The SNFP characterization activities will collect and evaluate the required data to support project initiatives and decisions related to interim safe storage and the path forward for disposal.

The DQO process is the basis for the activity specific SNF characterization requirements, termed the SNF Characterization DQO for that specific activity, which will be issued by the WHC or PNL organization responsible for the specific activity. The Characterization $\mathrm{Plan}$ prepared by PNL defines safety, remediation, and disposal issues (Abrefah 1994). The ongoing Defense Nuclear Facility Safety Board (DNFSB) requirement and plans and the fuel storage and disposition options studies provide the need and direction for the activity specific DQO process.

The hierarchy of characterization and DQO related documentation requirements is presented in this strategy. The management of the DQO process and the means of documenting the DQO process are described as we 11 as the tailoring of the DQO process to the specific need of the SNFP characterization activities. This strategy will assure stakeholder and project management that the proper data was collected and evaluated to support programmatic decisions. 
WHC-EP-0795

Rev. 0

\section{CONTENTS}

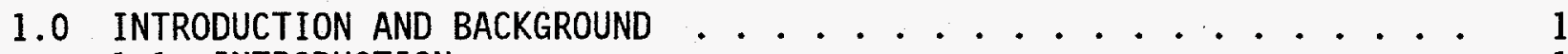



1.2 MANAGEMENT OF THE DATA QUALITY OBJECTIVES PROCESS . . . . . 3

1.3 DATA QUALITY OBJECTIVES GENERATION PROCESS . . . . . . . 4

1.4 PREVIOUS CHARACTERIZATION OF SPENT NUCLEAR FUELS $\ldots \ldots . .5$

1.5 PRESENT CHARACTERIZATION PROGRAM ........... 5

2.0 THE SPENT NUCLEAR FUEL PROJECT DATA QUALITY OBJECTIVES PROCESS . . . 6

2.1 PURPOSE AND SCOPE . . . . . . . . . . . . . 6

2.2 SPENT NUCLEAR FUELS PROJECT DATA QUALITY OBJECTIVES PROCESS . . 7

2.3 APPLICATION OF THE SPENT NUCLEAR FUELS PROJECT DATA

QUALITY OBJECTIVES PROCESS TO DEVELOPMENT OF SPENT

NUCLEAR FUELS PROJECT DATA QUALITY OBJECTIVES . . . . . . . 9

3.0 THE SPENT NUCLEAR FUEL PROJECT CHARACTERIZATION STRATEGY . . . . . 11

3.1 PROJECT GOALS AND OBJECTIVES . . . . . . . . . . . 11

3.2 DOCUMENT HIERARCHY ................... 11

3.2.1 Westinghouse Hanford Company Document Hierarchy . . . 11

3.2.2 Pacific Northwest Laboratory Document Hierarchy . . . 13

3.2.3 Document Approval and Distribution ......... 15

3.2.4 DQO Document Hierarchy . . . . . . . . . . 16

3.3 DATA QUALITY OBJECTIVES PROCESS REPORTING FORMAT . . . . . 16

3.4 SYSTEMS ENGINEERING INTERFACES ..................... 19

3.5 QUALITY ASSURANCE INTERFACES $\ldots \ldots \ldots$

3.6 EXTERNAL IMPACTS ON PROJECT . . . . . . . . . . . 20

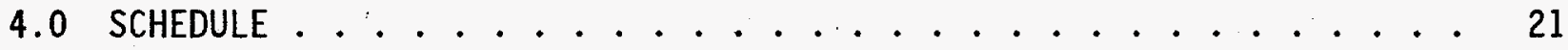

5.0 SPENT NUCLEAR FUEL PROJECT ORGANIZATIONAL POINTS OF CONTACT . . . . . 22

6.0 DOCUMENT REVISIONS ....................... 25

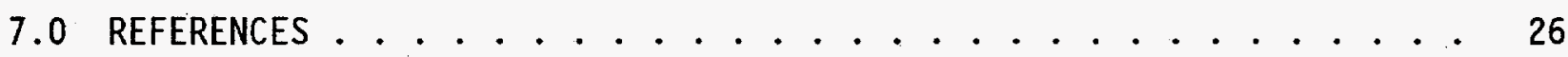


WHC-EP-0795

Rev. 0

\section{SPENT NUCLEAR FUELS PROJECT CHARACTERIZATION DATA QUALITY OBJECTIVES STRATEGY}

\subsection{INTRODUCTION AND BACKGROUND}

The objective of this document is to describe the strategy selected for a Data Quality objectives (DQO) based characterization activity in support of the Spent Nuclear Fuels Project (SNFP). Successful implementation of this strategy will ensure the required characterization data are provided to the SNFP and activities related to the Project in a timely and cost effective manner. This document provides a centralized focus for application of the DQO process as well as identifying the central role of the DQO process in the SNFP characterization activities.

\subsection{INTRODUCTION}

A strategy is required to implement and integrate the DQO process in the SNFP characterization activities. Westinghouse Hanford Company (WHC) and the Pacific Northwest Laboratory (PNL) have, since 1992, utilized the DQ0 process in the Tank Waste Remediation System (TWRS) characterization efforts (Babab 1994). WHC and PNL are teaming in the characterization of the SNF on the Hanford Site and are committed to using the DQO process outlined in this document.

The SNFP is responsible for programmatic management and project integration for the safe and systematic storage, and path forward to eventual disposition, for Spent Nuclear Fuel (SNF) at Hanford. This includes:

(1) Single Pass Reactor Fuel and N Reactor Fuel stored in the 105-K East/ 105-K West Basins; (2) N Reactor and K Reactor Fuel stored in PUREX; (3) the FFTF Driver and Test Fuel at various storage locations within the FFTF complex, and the FFTF Driver and Test Fuel within the reactor itself; (4) the Shippingport Core (Breeder Blanket) stored in T-Plant; (5) FFTF fuel, TRIGA fuel, LWR fuel, and miscellaneous test reactor fuel in retrievable storage at the 200 West Area Burial Grounds; (6) various fuel specimens stored in Pacific Northwest Laboratory (PNL) buildings; and (7) residual fuel with in the N Reactor Basin.

Resolution of near term issues related to the fuels stored in the $K$ Basins is the initial focus of the SNFP. N Reactor fuel has been stored for extended periods of time in the Hanford $K$ Basins with the termination of PUREX operations. Failed fuel is degrading with continued storage resulting in release of material to the basin water in the case of materials stored in the $K$ East Basin and the closed storage canisters in the case of materials in $K$ West. Information on the condition of the fuel may be necessary to support interim disposition decisions for the materials in both the open and closed storage canisters. It is desired to place the fuel in a safe interim storage condition for an extended period before ultimate disposal in a waste repository or other use. 
WHC-EP-0795

Rev. 0

The characterization activity for the Hanford SNF addresses the identified issues related to fuel condition, continued degradation and interim storage, availability of local hot cell capabilities and commitment of the SNF Project to the resolution of the identified vulnerabilities. Vulnerabilities in nuclear facilities are conditions or weaknesses that may lead to radiation exposure to the public, unnecessary or increased exposure to workers, or release of radioactive materials to the environment (DOE 1994).

The SNFP characterization activities are designed to provide analytical information sufficient to:

- Identify the minimum conditions necessary for transport and interim storage of the fuel within regulatory compliance (assuming applicability of the requirements set forth in 10 CFR 71 and 10 CFR 72); onsite shipment rules may be applied provided equivalent safety is demonstrated:

- Support process selection for transitioning of fuel from the current storage configuration to interim storage and maintaining the fuel in interim long-term dry storage.

- Establish safety envelopes and support development of the selected processes for implementation.

Characterization activities must assume that the duration for interim dry storage is up to 40 years. Characterization will also provide data to address issues related to final disposition.

Process selection and establishing safety envelopes are necessary to support issuance of the Hanford Spent Nuclear Fue 7 Environmental Impact Statement Record of Decision. Characterization activities are necessary to support implementation of the selected process. Results of the characterization activities may be used at a later date to establish direction for waste form performance tasks necessary to develop a path forward for ultimate fuel disposition.

Westinghouse Hanford Company has the lead responsibility for defining the envelope of requirements for characterization to support the SNFP for conducting in-situ characterization, preparation, and shipments of materials to the hot cells for examinations, requests for information from the hot cell. examinations, and interpretation of the results for the SNFP. Westinghouse Hanford Company is also responsible for supplying characterization information to support other project objectives.

Pacific Northwest Laboratories has the lead responsibility for characterization activities related to identifying regulatory and technical characterization needs, development of a Characterization Plan to obtain the identified technical, regulatory, and operational needs, preparation of facilities to carry out work detailed in the Characterization Plan, preparation of regulatory and technical documentation to support implementation activities detailed in the Plan, and evaluation of data gained 
WHC-EP-0795

Rev. 0

from characterization activities for technical significance and quality.

Pacific Northwest Laboratories also provides expert participation at all other levels of characterization.

\subsection{MANAGEMENT OF THE DATA QUALITY OBJECTIVES PROCESS}

The following guidelines focus the project management and ownership of the DQO process. Explicit elements for the management of the DQO process are defined below.

- Role of Activity Managers--The individual activity managers will own the DQOs associated with their programs. Such ownership includes, : but is not limited to:

- Conduct of DQOS

- Assuring active, timely, and appropriate stakeholder participation

- Defining technical aspects associated with their programs needs for characterization data

- Defending the technical conclusions found

- Actively supporting the management of the DQO process.

- Role of the SNF Projects Characterization Program Organization-Oversight of the DQO process will be maintained by the SNF Characterization Program organization. This organization will:

- Review all Examination Plans documenting the DQO process for consistency and completeness

- Coordinate (if requested by a activity manager) in organizing and/or facilitating the DQO process

- Assume responsibility for maintaining the DQO strategy and any requirement documents

- Provide a representative of the Characterization Program, if requested by the activity manager, to participate in their DQO efforts.

- Role of Laboratory and Analytical Services Support Organizations-The laboratory and support organization(s) that will be responsible for implementing the examination $\mathrm{plans}$ DQOS and will participate in all DQO efforts. Their role is focused on assuring the "practicality" of the requests called out by the activity managers, representatives, or other stakeholders. In addition, the laboratories and support organizations will provide recommendations for needed development to ensure that realistic data needs are defined and supported in a timely fashion. 
WHC-EP-0795

Rev. 0

- Conflict Resolution--A conflict resolution process, either between affected individual activity managers or among the stakeholders for a given DQO, will be established by the SNF Characterization Project Organization utilizing ad hoc teams of senior technical staff wel1 versed in the subject area (e.g., issue or program element) of the DQO.

- Review and Approval of DQOS--The DQO process will be documented in the SNFP Activity Specific Characterization DQO (Section 4.2). Al1 stakeholders will concur with the results of the DQO process by their documented participation in the process.

\subsection{DATA QUALITY OBJECTIVES GENERATION PROCESS}

The following three complementary approaches will be used to implement the DQO process.

- Facilitated Group Meetings--Utilization of subsets of stakeholders to provide focused input to the different steps of the DQO process where their technical or management role promises the greatest benefit. This approach will minimize the need to tie up large number of staff, yet will provide each group of stakeholders with an input to the DQO process.

- Facilitated Focused Stakeholder Interviews--Utilization of an interview process, by a facilitator of individual stakeholder, to gain the information needed for creation of the DQO. The facilitator has become knowledgeable in the subject area of the DQO by studying the applicable documentation. The DQO facilitator has a key senior technical staff member on the support team to facilitate information gathering and (as necessary) interpretation. This approach appears to work well for mature program elements.

- Unfacilitated Characterization Program Organization Initiatives (e.g., Specifying Information Needs)--Utilization by the SNFP Characterization manager of the EPA DQO guidelines (EPA 1993), to prepare a DQO utilizing characterization program resources. The Examination Plan DQO will then be reviewed by stakeholders and a conflict resolution meeting will be scheduled if needed. This approach will work best for narrowly defined specific sampling events.

Facilitated group meetings with the stakeholder is the preferred method to focus input to the $D Q 0$ process. The other two approaches will be used depending upon the scope and maturity of the activity. The intent of the SNFP is to employ the DQO process in developing the examination plans and requirements for each clearly definable characterization activity such as gas sampling selected closed canisters in the $K$ West Basin or characterization of sludge in the basins. 
WHC-EP-0795

Rev. 0

\subsection{PREVIOUS CHARACTERIZATION OF SPENT NUCLEAR FUELS}

Previous characterization activities for the SNF stored in the $K$ Basins were limited in scope and content. Fuel was originally expected to be reprocessed in PUREX after only a short residence time in the basins. Previous and ongoing characterization activities have included structural material corrosion monitoring, closed canister gas trap liquid level measurement, canister gas sampling, visual examinations, video surveys, and sludge and water sampling. Detailed destructive examinations of fuel elements after extended periods of basin storage are limited.

\subsection{PRESENT CHARACTERIZATION PROGRAM}

Characterization can be divided into the accelerated characterization to establish the present condition of the materials in the $\mathrm{K}$ Basins and characterization supporting interim and long term storage options. The SNFP will initially focus on the $\mathrm{N}$ Reactor and single pass reactor fuels and sludge in the $K$ Basins.

Accelerated characterization activities include a detailed review of historical records to establish the parameters for the materials stored in the $\mathrm{K}$ Basins, a preliminary visual examination of the material stored in K East, development of a data base on the initial conditions of the fuel, canisters, and sludge in both $\mathrm{K}$ Basins, gas and liquid sampling of closed canisters in $K$ West and evaluations of data collected during the in-situ examinations. Fuel, canister, and sludge samples will be selected and removed from the basins and transported to the hot cells for detailed examinations.

The characterization activities supporting decisions on interim and long term storage are in the development stages. The Characterization Plan prepared by PNL outlines the logic and data that could be obtained to support the preferred path to interim disposition including some of the options being evaluated. 
WHC-EP-0795

Rev. 0

\subsection{THE SPENT NUCLEAR FUEL PROJECT DATA QUALITY OBJECTIVES PROCESS}

\subsection{PURPOSE AND SCOPE}

The activity managers and characterization program will use the DQO process to support SNFP decisions in the areas of fuel handling, encapsulation, repackaging, sludge mitigation, and interim and final storage.

The DQO Process is a strategic and a tactical planning tool that is both flexible and rigorous enough to respond to evolving SNFP programmatic and technical requirements, functions, and constraints. Characterization data requirements that are identified using the DQO process are called Data Quality Objectives (DQOS).

Characterization data is defined to be quantitative or qualitative information that supports characterization program element inputs to fuel handling, encapsulation, repackaging, sludge mitigation, and interim and final storage decisions. For example, measuring the mass of fissile material in sludge represents a quantitative DQO. A video survey of the structural and mechanical integrity of fuel and canisters represents a qualitative DQO.

Dependent on the SNFP problem being examined, application of the DQO process may yield one, or more, or some combination of, quantitative or qual itative characterization DQOs. Whether quantitative or qualitative, a11 SNFP DQOS are developed based on requirements defined in NRC, DOE, EPA, and State of Washington regulations. questions:

SNFP characterization DQOS are developed to answer several major

- What are the specific SNFP issues being examined?

- What SNFP decision (or decisions) must be made?

- What characterization data is required to support the SNFP decisions?

- How will the characterization data be used to support the SNFP decisions?

- How will the characterization data be collected, sampled, and analyzed, and what engineering and statistical methods will be used to evaluate the data?

Details associated with implementation of the DQO process are contained in EPA 1993. The SNFP DQO process is based exclusively upon this guidance document. 
WHC-EP-0795

Rev. 0

\subsection{SPENT NUCLEAR FUELS PROJECT DATA QUALITY OBJECTIVES PROCESS}

The SNFP DQO process follows a logical progression of data requirements definition and identification through proposed data collection, analysis, and evaluation approaches.

A11 data requirements are based upon a particular problem definition and an identification of SNFP disposal decisions the characterization data is intended to support. Next, an identification of the characterization data (the decision variables) that support the decisions is performed. The identification of error tolerances for the SNFP decision and the associated measurement and estimation uncertainties of the characterization decision variables is then accomplished. A logic that explicitly defines how values of the characterization data triggers various decisions is developed. Finally, a sampling and analysis approach to be used for data collection is determined so as to minimize the cost of sampling and analysis while meeting the precision and accuracy requirements needed to support the SNFP decisions.

A11 SNFP characterization data requirements are developed by coordinating the needs of project, program element, and regulatory stakeholder with explicit considerations of programmatic, technical, and information availability constraints of the organizations that support operations, sampling, and analysis efforts.

The SNFP stakeholders include SNFP characterization personnel, SNFP operations personnel, regulatory specialists, laboratory personnel, sampling personnel, statistical support personnel, and subject matter experts. Stakeholders are to offer DOE-RL, DOE-HQ, NRC, WHC, EPA, and Washington State Department of Ecology perspectives on SNFP decisions and data requirements to support the decisions for SNFP DQOS.

The SNFP DQO process is designed to meet evolving SNFP programmatic and technical requirements, functions, and constraints while maintaining a significant degree of flexibility, rigor, and control in characterization data requirements identification. While the steps of the SNFP DQO procesS are 7 isted sequentially, there is considerable iteration and feedback between the steps to ensure that all SNFP characterization data requirements and sampling and analysis approaches support the particular SNFP decisions under investigation.

\section{Step 1. State the Problem.}

The purpose of this step is to clearly define the SNFP problem and issues to be investigated. The context of the SNFP problem is established by reviewing and summarizing existing information and describing the approach(es) under consideration to resolve these issues. This will enable decisions to be made to solve the problem. During this step, the stakeholders that should be involved in the SNFP DQO development are identified, the schedule for the SNFP DQO process is defined, the core group of SNFP decision makers who are identified, and the SNFP DQO documentation file and library is started. Any practical constraints (programmatic, technical, or information) that might affect the approaches to problem resolution are identified. 
WHC-EP-0795

Rev. 0

Step 2. Identify the Decision.

The SNFP decisions (concerning isolation, interim storage, and final disposition) that must be made based on the characterization data are identified in this step. Possible decision outcomes and the consequences of the decisions are identified. Each decision, the expected outcomes, and the consequences of the decision are correlated to the issues and problems identified in the previous step.

Step 3. Identify the Inputs to the Decision.

The information needs required to make the SNFP decision are specified, and the data that must be collected to generate this information is specified in this step. For each decision identified in the previous step the issues which need to be resolved to enable this decision are identified. The information needs associated with these issues are (i) the specific decision variable, (ii) whether the variable is quantitative or qualitative, (iii) the type of decision variable (average, upper or lower confidence value, variance, maximum or minimum, etc.), (iv) the units of measurement of the decision variable, and (v) the associated rationale for the variable are defined. Historical quantitative and qualitative information for each decision variable is identified and obtained at this time. This step clearly and completely identifies the SNFP characterization decision variables necessary to support the SNFP decision.

Step 4. Define the Study Boundaries.

Spatial and temporal parameters that constrain the SNFP decision and the SNFP characterization decision variable are determined in this step. The spatial area (or volume) to which a SNFP decision applies and within which the data should be collected is defined. Both operational and statistical sampling approaches are identified at this time. The timeframe during which each SNFP decision is made is specified. The correlation between when each SNFP decision variable is needed to support the specific SNFP decision is then developed.

Step 5. Develop a Decision Rule.

The objective of this step is to clearly define the logic that is used for making a SNFP decision based upon the SNFP characterization data. Both graphical and textual formats of the decision rule are developed. The decision rule is portrayed in an "if... then..." manner that defines conditions of each of the decision variables that would either trigger another decision to be made or a specific action to be taken. The decision rule correlates all decisions with all decision variables and spatial and temporal conditions defined in the previous steps.

Step 6. Specify Acceptable Limits on Decision Errors.

Acceptable decision error limits (error tolerances or error budgets) are quantitatively identified in this step for each based on (i) the 
WHC-EP-0795

Rev. 0

consequences of making correct and incorrect decisions, ( $i i)$ the desired confidence associated with making a correct decision, and ( $i i i)$ the associated risk of making an incorrect decision. Information needs that are expected to cause the greatest impact on the error limits for the decision are identified. Total measurement precision and accuracy for each decision variable is defined. Total measurement precision and accuracy for each decision variable is due to (i) variability associated with sampling locations and data collection efforts for the decision variable, (ii) analytical variability associated with the test methods and (iii) the underlying spatial distribution or variability of the decision variable in an $(x, y, z)$ system.

Step 7. Optimize the Design.

The purpose of this step is to determine an optimal method to collect the required SNFP characterization data that supports the SNFP decisions. Such an optimal method balances the cost of sampling and analys is with the requirements associated with decision error limits defined in the previous step and the total variability of the decision variable used to support the decision. Trade-offs are made between (i) the cost of sampling and analysis and (ii) the desired error budget and the decision variable accuracy and precision requirements. Based upon such tradeoffs, a sampling design that meets SNFP stakeholder data requirements is determined.

\subsection{APPLICATION OF THE SPENT NUCLEAR FUELS PROJECT DATA QUALITY OBJECTIVES PROCESS TO DEVELOPMENT OF SPENT NUCLEAR FUELS PROJECT DATA QUALITY OBJECTIVES}

There is a very broad spectrum of SNFP characterization requirements and systems that will accomplish the SNFP objectives. The SNFP characterization DQOS and data requirements that can support such decisions range from being well defined to completely unknown. Similarly, SNFP systems that can support these decisions range from immature, unfielded, undeveloped systems to we11developed operational systems.

The SNFP DQO process offers a significant degree of flexibility for characterization data requirements identification by adapting to the relative maturity of systems used to support the decision and the quantity and quality of information available.

- The SNFP DQO process may only be used to define the problem and identify decisions in which SNFP characterization data may be required (SNFP DQO Process Steps 1 and 2). The SNFP DQO process would be used to define the scope and extent of an integrated data collection effort. For example, if a repackaging system were so technologically immature to be unable to identify detailed data requirements for the system, identification of the decisions that would be made using characterization data is reasonable. 
WHC-EP-0795

Rev. 0

- In addition to problem definition and decision identification, application of the SNFP DQO process may be extended to identify specific characterization data (the decision variables) that will support the decisions (SNFP DQO Process Steps 1, 2, 3, and 4). For example, the SNFP DQO process is used for decision variable identification when the questions "what measurements are needed" or "how much material is needed" are the only questions of concern.

- Given a complete identification of decision variables that support SNFP decisions, the SNFP DQO process may be used to develop the logic that defines how values of the characterization data will trigger various decisions (SNFP DQO Process Steps 1, 2, 3, 4, and 5). The SNFP DQO process may a7so be employed to determine measurement and estimation uncertainties inherent in the characterization decision variables (SNFP DQO Process Steps 1, 2, 3, 4 , and 6). Similarly, both the decision logic and the error tolerances may be undertaken for the SNFP decision (SNFP DQO Process Steps 1 through 6). Several examples include: (i) two or more systems will require an integrated data collection effort, but no data is available to develop an optimal sampling and analysis plan; (ii) data is required to describe the performance or effectiveness of a technologically immature system; (iii) screening or pilot studies where decision rules and acceptable error tolerances can be defined and decisions will be made based on a statistical evaluation of the resulting data; or, (iv) the primary objective of the study is to provide appropriate estimates of uncertainty.

- In the most complete sense, the SNFP DQO process may be used to determine an optimal sampling and analysis approach for data collection so as to minimize the cost of sampling and analysis while meeting the data precision and accuracy requirements needed to support the SNFP decisions (SNFP DQO Process Steps 1 through 7). Such an optimization is accomplished, for example, when the probability of making incorrect decisions based on sample results must be controlled to acceptable levels to minimize costs and health and safety risks. Similarly, SNFP sampling and analysis optimization would be used when the SNFP system being examined is sufficiently mature so that operationally meaningful data requirements can be determined.

Although such a structured and stratified application of the SNFP DQO process sounds unwieldy, the flexibility offered by the SNFP DQO process is documented by simply indicating, for each SNFP DQO, which steps of the SNFP DQO process were completed and which steps were not. This clearly articulates the completeness of application of the SNFP DQO process to SNFP decisions, and it offers significant defensibility to outside review organizations (e.g., DNFSB and GAO) that are interested in SNFP characterization progress. 
WHC-EP-0795

Rev. 0

\subsection{THE SPENT NUCLEAR FUEL PROJECT CHARACTERIZATION STRATEGY}

The approach to characterization of the SNF stored at the Hanford Site is similar to the phased approach taken by the Tank Waste Remediation System (TWRS) (Babad 1994). The SNF characterization activities will collect and evaluate the required characterization data needed at a specific time to support project programmatic initiatives and decisions.

\subsection{PROJECT GOALS AND OBJECTIVES}

The goals of the SNFP at the Hanford Site is to provide safe, economic, environmentally sound management of Hanford SNF in a manner which stages the material to its final disposition. The strategic objectives for the Project are the management and safe disposition of all SNF on the Hanford Site. Initial emphasis is being placed on the $K$ Basins because they contain the largest amount of SNF onsite, the SNF in them is known to be degrading with time, and they are near the Columbia river.

One of the principal objectives of the SNFP is the safe isolation of the fuel in the $K$ Basins from the environment. Supplementary objectives are to:

- Establish near-term safe storage in K Basins

- Complete NEPA process to obtain a decision clarifying how and where the SNF will be managed onsite

- Define and establish alternative interim storage onsite or transport offsite to support implementation of the NEPA decision

One of the issues relates to the fact that much of the SNF in the various facilities has not been fully characterized. In addition, in the case of the $K$ Basins the state of the fuel is known to be degrading although the extent of the degradation has not been quantified. The specific objective of the characterization activities are to establish the state of the materials in these facilities to support parth forward decisions for near term safe storage.

\subsection{DOCUMENT HIERARCHY}

The WHC and PNL document hierarchy governing the SNFP characterization activities are different due to the different roles the two organizations have within the SNFP.

\subsubsection{Westinghouse Hanford Company Document Hierarchy}

The WHC hierarchy of documentation governing the SNFP characterization activities is illustrated in Figure 1. The Characterization Program Management PIan utilizes resources of WHC and PNL to address critical issues 
WHC-EP-0795

Rev. 0

Figure 1. Hierarchy of WHC Spent Nuclear Fuel Project Characterization Documentation.

Characterization Program Management

Plan for Hanford SNF

WHC/PNL

SNF Project Managers Define Safety, Remediation and Disposal Issues Requiring New Data.

SNF Characterization Plan
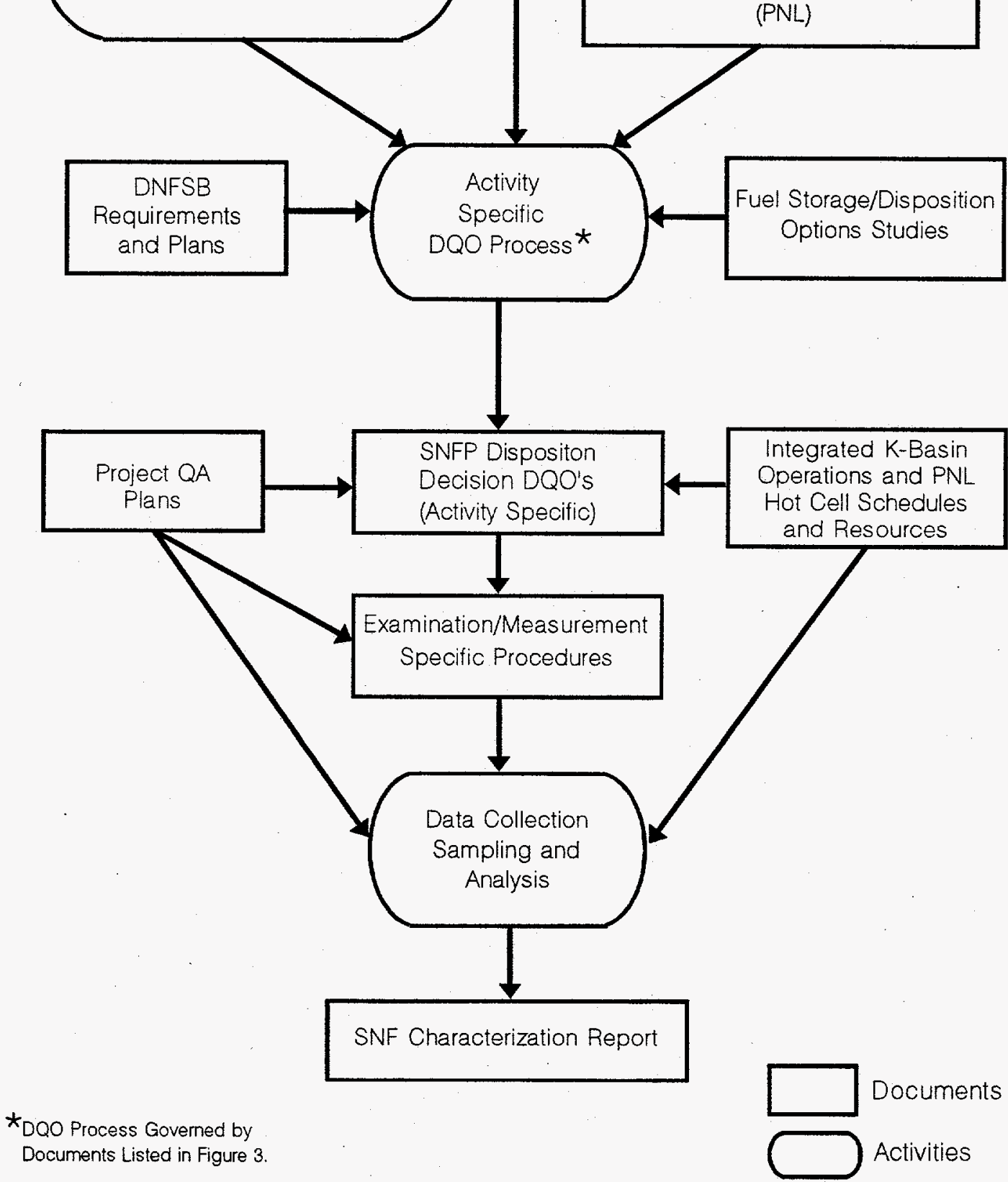
with the SNF stored at the Hanford Site (Gerber 1994). The Characterization Plan prepared by PNL along with the SNFP define isolation (safety), interim storage, and final disposal issues. The characterization Plan describes the information needs that may be required to support development of the SNF disposition pathway, and defines the associated SNF sampling and testing required to satisfy these information needs (Abrefah 1994). The ongoing DNFSB recommendations and corresponding plans and the fuel storage and disposition options studies provide the need for an activity specific DQO process. The DQO process becomes the basis for an activity specific SNF characterization DQO which will be issued by the organization with the SNFP performing the specific activities including both WHC and PNL performing organizations. The SNFP QA plans and requirements will also provide input to the characterization. plan.

A set of examination and measurement specific procedures wit1 be prepared by the performing organization for approval by the requesting organization who prepared the SNF Characterization DQO. The examinations specific procedures will require the routine facility approval for implementation.

Following approval of the procedures the actual data collection, sampling, and analys is will be conducted governed by the integrated facility schedules and the Project QA requirements. A SNF characterization report will be prepared and cleared for release in a timely manner and distributed to all interested parties at the completion of the measurements. Interim reports will be prepared as needed to meet project schedules and decisions.

\subsubsection{Pacific Northwest Laboratory Document Hierarchy}

The PNL hierarchy of documentation governing the SNFP characterization activities is illustrated in Figure 2. The PNL hierarchy shows an additional class of documents dealing with the test methods and procedure requirements for the examinations to be conducted in the hot cells.

The Sampling Strategy document is a joint WHC and PNL document which describes the approach to be used in selecting 105-K Basins SNF samples for characterization testing at PNL. It relates this approach to WHC and DOE strategies for developing the pathway for 105-K Basins SNF disposition.

The SNF Project DQOs are WHC documents which described the Data Quality objectives (DQOS) required to support DOE disposition pathway decisions. These documents include those aspects of the DQO process related to problem definition and associated information requirements.

Each Examination. Plan/DQ0 is a PNL document which describes the issues to be addressed, data and information needs to be obtained, and the SNF samples to be tested in a given shipment of SNF from the 105-K Basins to the PNL test facilities. The Examination Plans includes those aspects of the DQO process related to the laboratory tests and analyses to be performed on the SNF samples contained in a shipment, justification for the sample selection and testing, definition of the tests required, and data accuracy requirements. 
WHC-EP-0795

Rev. 0

Figure 2. Hierarchy of PNL Spent Nuclear Fuel

Project Characterization Documentation.




WHC-EP-0795

Rev. 0

Each Examination Plan will reference the applicable SNF Project Disposition Decision $\mathrm{DQO}(\mathrm{s})$ to relate the sample characterization testing to the disposition decision requirements.

Test P1ans are PNL documents which describe the individual laboratory tests involved in providing data for an information need. The Test Plans describe the test types and procedures, equipment requirements, accuracy capabilities, and data reduction requirements. Each information need identified in the Characterization Plan for Hanford Spent Nuclear Fuel will have an associated Test Plan.

Procedures are step by step guidance for the operation of Taboratory and hot cell apparatuses and test equipment at PNL.

Test Instruction are internal directives from PNL project management to technical staff which describe in detail the samples to be tested and procedures to be used in meeting the requirements of the Examination PTans/DQOS.

\subsubsection{Document Approval and Distribution}

The SNF Characterization associated DQO documentation prepared by WHC and PNL will be approved by the following as a minimum:

- Manager WHC SNFP characterization activities

- Manager PNL SNFP characterization activities

- Manager WHC SNFP Quality Assurance

- DOE/Richland Operations Office Representative to the SNFP for characterization

The following individual, or their representative, in addition to the ones listed above will participate in the DQO process and be identified in the SNF Characterization DQO as to their participation and concurrence. Selected individuals may also approve specific DQOS.

- Manager of the performing organization responsible for conducting the specific examinations

- Managers of the facilities where the examinations will be conducted if different from the performing organization

- Managers of all the organizations utilizing the data for project decisions

- Manager of Regulatory Integration and Public Involvement for the SNFP as appropriate to the characterization activities

- Any public stakeholder identified by the SNFP manager of Regulatory Integration and Public Involvement for Approval of the specific DQO 
WHC-EP-0795

Rev. 0

- Selected onsite and offsite experts in the particular measurement activity or property being evaluated.

The SNF Characterization DQOS will be cleared for release and distributed to all interested parties within WHC and PNL, as well as the DOE/Richland Operations office representative to the SNFP, and the State of Washington Departments of Ecology and Health.

\subsubsection{DQO Document Hierarchy}

The hierarchy of $\mathrm{DQO}$ documents is shown in Figure 3 . The guiding document of the process is the Environmental Protection Agency document (EPA 1993) providing guidance for planning the data collection utilizing DQO. The $\mathrm{DQO}$ documents prepared for the TWRS provide lessons learned support for the SNFP DQO documents. This strategy document provides the basis and linkage for the preparation of the SNF Characterization DQOS which document the DQO process including identification of all the DQO participants.

\subsection{DATA QUALITY OBJECTIVES PROCESS REPORTING FORMAT}

The SNFP DQO strategy in this document outlines a $\mathrm{plan}$ of developing issue-based data requirements through the DQO process. In an effort to ensure compatible, comparative, and somewhat uniform products from the many anticipated DQO applications, a recommended DQO process reporting format outline follows.

Signoff Cover Sheet, Title Page, and Table of Contents

The DQO documents prepared by WHC should be issued as WHC supporting documents (SD). This facilitates periodic updates and streamlines the approval process.

The DQO documents prepared by PNL will be issued as PNL controlled documents.

Executive Summary. Includes a 1 to 3 page summary of the problem and the DQO outputs contained in the DQO report. The Executive Summary should describe the problem, identify what data needs to be gathered to resolve the problem, and how the data obtained will be used to solve the problem.

1.0 Introduction. A brief description of the program area, why DQOS were developed for this problem, the expectations of the participants and stakeholders, and what is contained in the report. The introduction should help the reader understand what DQO category was chosen and why, and any $\mathrm{plans}$ for revisiting the DQO process, as more data become available. 
WHC-EP-0795

Rev. 0

Figure 3. The Hierarchy of Data Quality Objectives Documents.

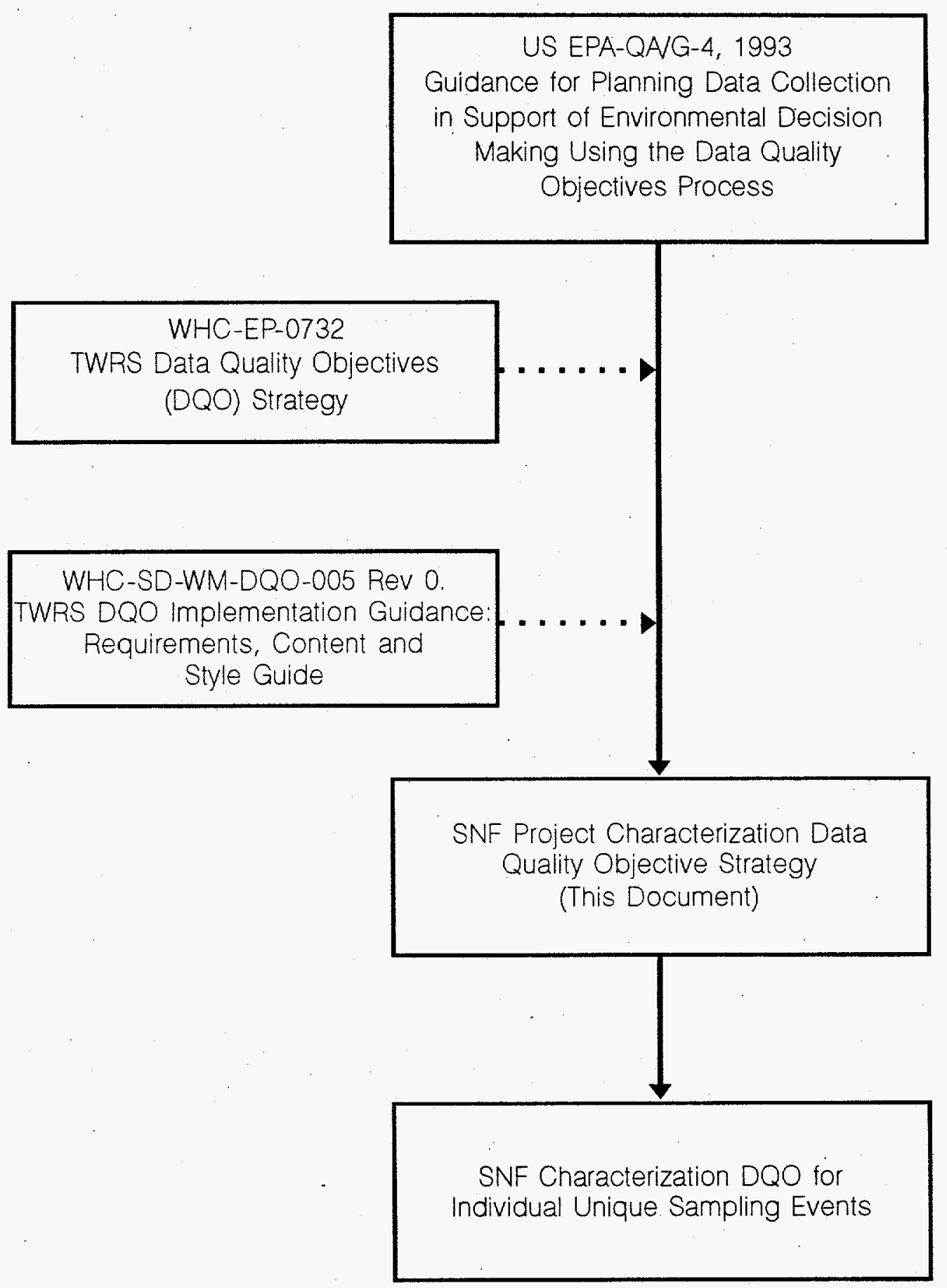

Direct Linkage

...... Lessons Learned Support 
WHC-EP-0795

Rev. 0

2.0 DQO Step 1: State the Problem. An overview of the background, statement of the problem, questions and major issues related to the problem, general approaches to addressing the problem, and practical constraints should be covered. A list of DQO process participants should also be provided. This section should succinctly state why the data is required and when the data is needed.

3.0 DQO Step 2: Identify the Questions to be Answered. Identify the decisions that address the problem or what questions must be answered. The primary decision or question is stated. Potential answers to the decision or question are presented. The priority of other decisions in the project are indicated relative to the primary decision.

4.0 DQO Step 3: Identify the Input to the Decisions or Questions. Specify the data dependent variables and the supporting rationale required to make the decisions or answer the questions. Specify other input required to make the decision. Defend the need for ancillary data that may not be used directly to make the decisions but may provide collaborative evidence to support the decisions.

5.0 DQO Step 4: Decision/Question Boundaries. Describe the spatial and temporal boundaries. Describe the population to which the decisions will be applicable. Describe particular physical, technological, or information constraints that support a refined contextual statement of the problem (DQO Step 1). Describe the time period for decisions and when data must be available for decision making.

6.0 DQO Step 5: Decision Rules. Decision rules for the data that triggers a decision and for the answers to specific questions that trigger a decision should be presented with the rational for choosing those decision rules. For clarity, a decision logic may be included.

7.0 Decision Error Tolerances. The consequences of incorrect decisions should be discussed. The decision maker's acceptable probabilities of making incorrect decisions under various scenarios should be shown with the appropriate rationale for such decision error tolerances.

\subsection{DQO Step 7: Sampling and Analysis Design Options.}

8.1 Historical Data Evaluation. Provide preliminary assessment of pertinent available data and quantification of statistical uncertainties.

8.2 Assumptions. Present key assumptions upon which performance of the design was evaluated and plans for validating those assumptions.

8.3 Sampling and Analysis Design. Present recommended design along with a rationale for selecting that design. Alternative designs maybe discussed. The number, placement, and type of samples and the required analyses should be outlined. Analytical specifications should be provided. 
WHC-EP-0795

Rev. 0

8.4 Decision Approach. Specify how the decisions will be made given inherent uncertainties. Specify statistical approached that will be applied to the data to ensure decision error tolerances are met. Provide a preliminary data quality assessment approach.

9.0 References. Cite all references that are included in the document.

10.0 Participants. Identify all participants in the various meetings, focused interviews, or program initiatives conducted to prepare the DQO.

This general outline should be followed when documenting DQO process results. If not a $11 \mathrm{DQO}$ steps are complete, adequate justification for not completing each step should be provided in the appropriate sections of the report and if applicable, plans for completing those DQO steps should be outlined.

\subsection{SYSTEMS ENGINEERING INTERFACES}

The Sitewide systems engineering study termed the Capstone Study identified the functions and requirements and linkages for the cleanup of Hanford (Holmes 1994). Function 4 titled remedy unsafe and unacceptable conditions includes a function (i.e., 4.7) devoted to "store, treat, and disposition special nuclear material/nuclear material/nuclear fuel (SNM/NM/NF) material.

Under Function 4.7, "store, treat, and disposition SNM/NM/NF materials," is the Function 4.7.4.1.1 "Characterize Material for Treatment Determination (Storage)." The SNFP characterization activities fall within this Capstone Study function. This function covers the activities necessary to characterize the SNM/NM/NF materials onsite for treatment for storage and disposition.

The Function 4.7.4.1.1 to characterize the SNF onsite is linked to multiple functions such as: definition of materials/storage/treatment/ disposition requirements Function 4.7.2.1.4, deactivate facilities, stabilize reactive materials, Function 4.1.1.4.3.1, etc.

The SNFP Technical Baseline Document establishes the basel ine functions, requirements, and interfaces to a level necessary to complete the SNFP mission as defined in the companion Mission Analysis Report. The technical baseline document defines the activities and provides the linkage for the characterization activities covered by this DQO strategy document.

\subsection{QUALITY ASSURANCE INTERFACES}

A comprehensive Quality Assurance (QA) program for WHC has been developed and implemented. The QA program is documented in WHC-CM-4-2, "Quality Assurance Manual." This program is utilizing WHC-CM-4-2 as the governing WHC QA requirements for the SNFP. 
WHC-EP-0795

Rev. 0

Pacific Northwest Laboratories (PNL) will provide support for the SNFP fuel characterization. Characterization activities performed by PNL will comply with a project-specific QA plan which ensures compliance with the criteria of NQA-1 and other related requirements.

\subsection{EXTERNAL IMPACTS ON PROJECT}

The project goals and objectives as well as the strategy and schedule are subject to the external stakeholder and regulatory agencies providing oversight and impact to the project. The Defense Nuclear Safety Board (DNFSB) has identified vulnerabilities and safety issues related to the onsite management of the SNF. This combined with the Tri-Party agreements provides the disciplined structure from which to prepare SNFP strategy. The regulatory rulings and regulations provide the framework and limitations within which the project activities must function. If any of these change for whatever reason the SNFP will be impacted. If for example the loose material in the basins (termed sludge) is ruled to be SNF a particular set of regulations and actions apply. If however the material is ruled to be transuranic waste or possibly mixed transuranic waste a different set of regulations and actions will apply.

Similarly if the agreed-to activity covered by the Tri-Party agreements are revised the SNFP plan, goals, etc. must be updated to reflect the changes. In addition, Department of Energy funding will have a strong impact on programmatic strategy and schedules. 
WHC-EP-0795

Rev. 0

\subsection{SCHEDULE}

A detailed integrated schedule is being prepared for the SNFP. The Tri-Party agreement milestones governing the long term SNFP schedule are summarized in Table 3 . Short term project specific schedules are being produced for such things as the video survey of K East, closed canister gas and water sampling, transportation of samples of fuel and sludge to the hot cells and laboratories for examinations. These schedules are integrated with available resources and the facility and performing organization schedules. The short term schedules are to be part of the SNF Characterization DQOS and as such are integral to the DQO process and the examination planning activities.

Table 3. Spent Nuclear Fuel Project Tri-Party Agreement Milestones.

\begin{tabular}{|c|c|}
\hline - Issue notice of intent for $\mathrm{N}$ Reactor Fuel EIS & June 1994 \\
\hline - Begin K East Basin fuel encapsulation. & June 1994 \\
\hline Complete Site Wide Systems AnaTysis & July 1994 \\
\hline $\begin{array}{l}\text { - Submit engineering study on moving } \mathrm{K} \text { East fuel to } \\
\mathrm{K} \text { West Basin }\end{array}$ & September 1994 \\
\hline $\begin{array}{l}\text { - Submit schedule for disposing of contaminated } K \text { East } \\
\text { Basin water }\end{array}$ & October 1994 \\
\hline $\begin{array}{l}\text { - Provide a schedule for fuel/sludge encapsulation and } \\
\text { contaminated water removal/replacement to regulators }\end{array}$ & March 1994 \\
\hline - $\quad$ Submit a DOE Signed Change Package for New Facilities & June 1995 \\
\hline - $\quad$ Begin $K$ East Basin sludge encapsulation & June 1996 \\
\hline $\begin{array}{l}\text { - Negotiate long-term fuel storage and disposition with } \\
\text { regulators }\end{array}$ & June $30,1996 *$ \\
\hline - Complete $\mathrm{K}$ East fuel and sludge encapsulation & December 1998 \\
\hline Remove encapsulated fuel and sludge from $K$ Basins & December 2002 \\
\hline $\begin{array}{l}\text { - Remove, replace, or treat contaminated K East Basin } \\
\text { water }\end{array}$ & $T B D^{*}$ \\
\hline
\end{tabular}

*Enforceable milestones. 
WHC-EP-0795

Rev. 0

\subsection{SPENT NUCLEAR FUEL PROJECT ORGANIZATIONAL POINTS OF CONTACT}

The SNFP organizational points of contact are summarized in Figure 4 for WHC and Figure 5 for PNL. The organizational points of contact DOE/RL, and the Washington State Departments of Ecology and Health are 1isted in Table 4.

Table 4. Spent Nuclear Fuel Project Organizational Department of Energy and Washington State Points of Contact.

\begin{tabular}{||l|l||}
\hline \multicolumn{1}{|c|}{ Organization } & Individual \\
\hline $\begin{array}{l}\text { Department of Energy } \\
\text { Richland Operations Office }\end{array}$ & \\
\hline Director, Nuclear Materials Division & J. L. Daily \\
\hline $\begin{array}{l}\text { Acting Manager, Interim Storage and Disposition } \\
\text { Project }\end{array}$ & G. D. Trenchard \\
\hline $\begin{array}{l}\text { Washington State } \\
\text { Department of Ecology }\end{array}$ & D. Silver \\
\hline Department of Health & A. W. Conklin \\
\hline
\end{tabular}


WHC-EP-0795

Rev. 0

Figure 4. Westinghouse Hanford Company Organizational Points of Contact for the Spent Nuclear Fuel Project.

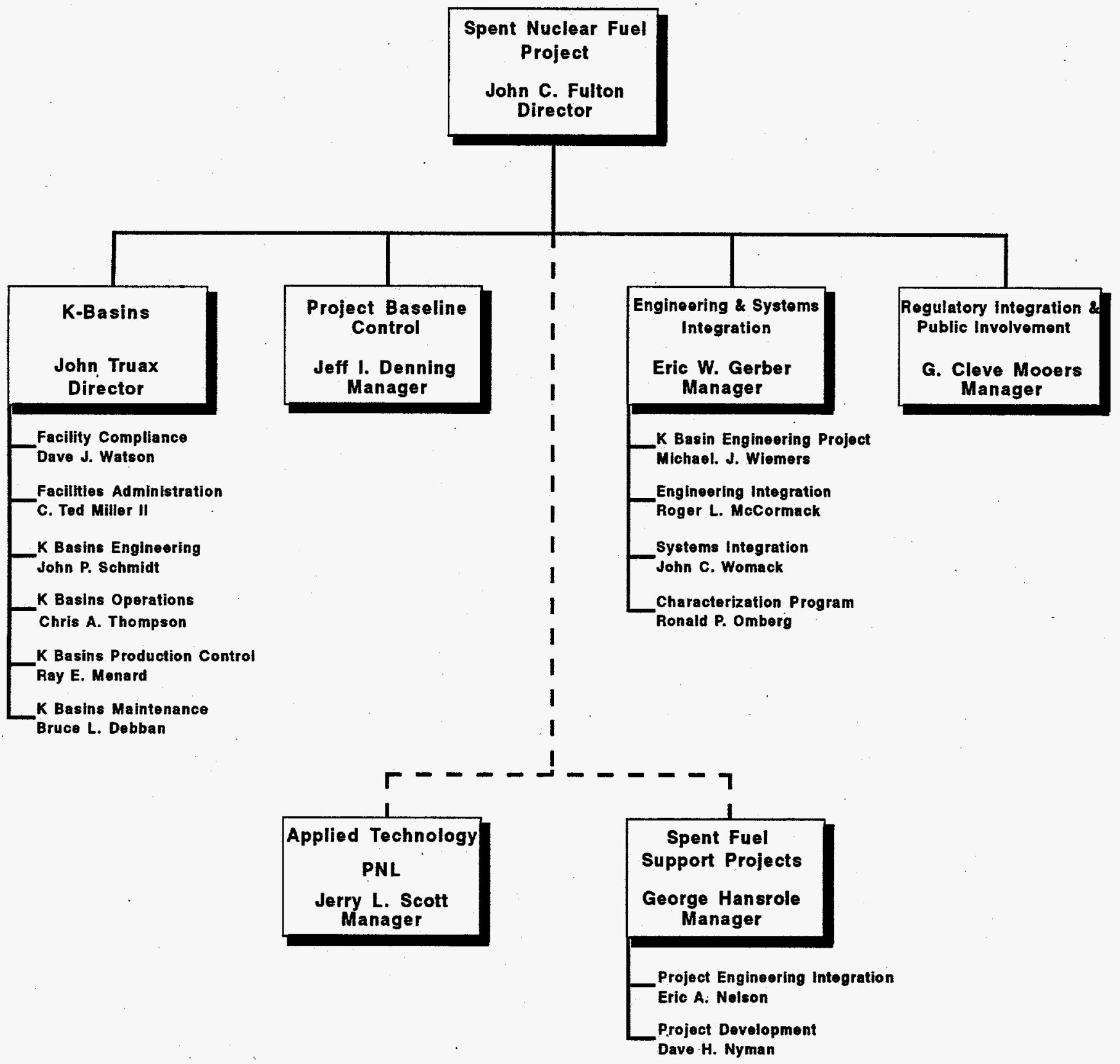


WHC-EP-0795

Rev. 0

Figure 5. Pacific Northwest Laboratory Organizational Points of Contact for the Spent Nuclear Fuel Project

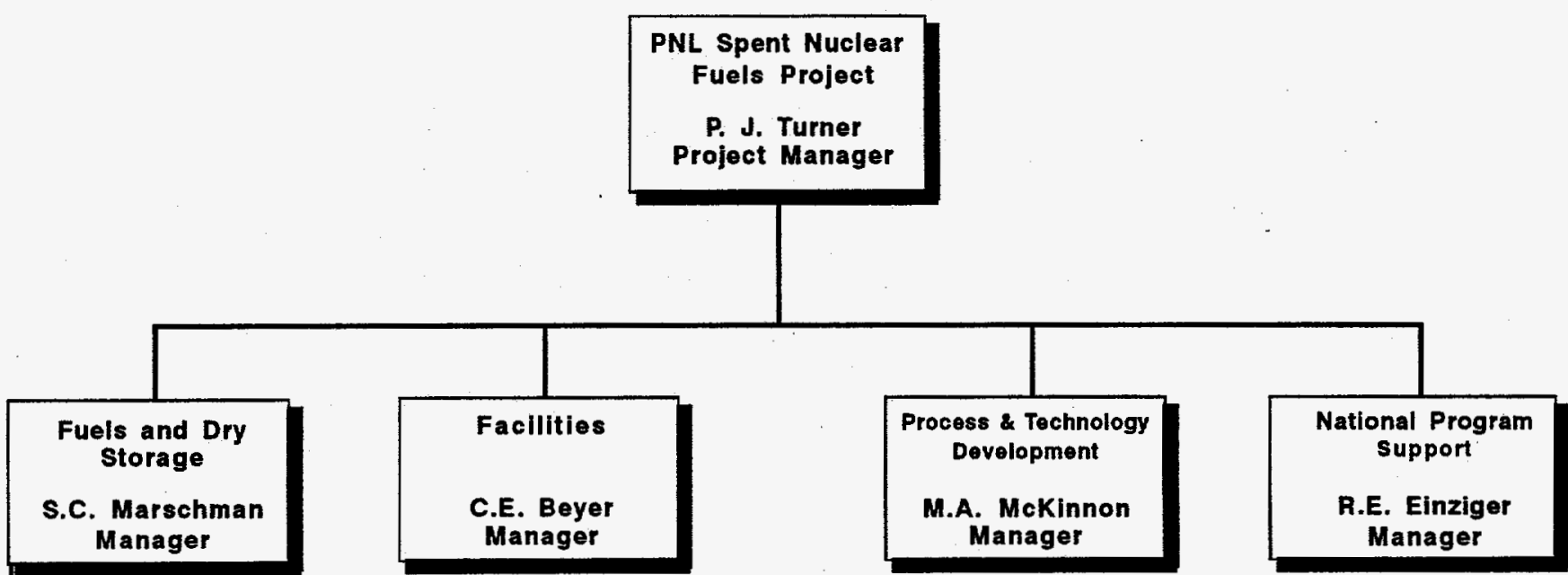

Hot Cell Operations

J.M. Seay 
WHC-EP-0795

Rev. 0

\subsection{DOCUMENT REVISIONS}

This DQO strategy document will not be maintained under configuration control. The document will be reviewed annually during the anniversary month of issue for the project 1 ife and updated and revised as necessary to accurately reflect the SNFP. The decision to update the document and issue a revised document or provide updated sections witl be made by the WHC manager of the characterization program.

A revision to this document may be requested from the non-WHC program participants if significant change in strategy, scope, objectives, schedule, etc., warrant a revision. 
WHC-EP-0795

Rev. 0

\subsection{REFERENCES}

Abrefah, J., T. Thornton, L. E. Thomas, F. B. Berting, and S. C. Marschman, 1994, "The Characterization Plan for Hanford Spent Nuclear Fuel," Battelle Pacific Northwest Laboratory, Draft, July 1994.

Babad, H., S. M. Blacker, K. S. Redus, J. G. Hill, J. L. Scott, 1994, "TWRS Data Quality Objectives Strategy," WHC-EP-0732, Richland, Washington.

DOE, 1994, "Plan of Action to Resolve Spent Nuclear Fuels Vulnerabilities, Phase I, Volume I, Executive Summary," U.S. Department of Energy, February 1994.

EPA, 1993, "Guidance for Planning for Data Collection in Support of Environmental Decision Making Using the Data Quality Objectives Process," EPA QA/G-4 Interim Final, U.S. Environmental Protection Agency.

Gerber, E. W., P. J. Turner, 1994, "Characterization Program Management Plan for Hanford Spent Nuclear Fuel, "April 1994.

Holmes, J. J., 1994, "Systems Engineering Functions and Requirements for the Hanford Cleanup Mission, First Issue," WHC-EP-0722, Rich1and, Washington. 
WHC-EP-0795

Rev. 0

\section{DISTRIBUTION}

Number of copies

OFFSITE

1

Washington State Department of Ecology

P.0. Box 47600

Olympia, Washington 98504-7600

D. Silver

1

Washington State Department of Health

Airdustrial Park

Building 5, Mail Stop LE-13

01ympia, Washington 98504-0095

A. W. Conklin

$\underline{\text { ONSITE }}$

3

U.S. Department of Energy, Richland Field office

S. S. Clark

R3-81

J. L. Daily II

R3-81

G. D. Trenchard

R3-81

5

Mac Technical Services Company

G. Baston

R3-82

G. F. Christian

B1-42

R. P. Denise

R3-82

K. S. Redus

B1-42

J. A. Sheriff

B1-42

10

Pacific Northwest Laboratory

J. Abrefah

R. E. Einzinger

S. C. Marschman

T. D. Pyecha

J. L. Scott

T. A. Thornton

K. M. Tominey

P. J. Turner

(2)
P7-14

P7-14

P7-18

P7-14

K1-22

P7 -18

K7 -97

P7-35 
WHC-EP-0795

Rev. 0

DISTRIBUTION (cont.)

Number of Copies

ONSITE

Westinghouse Hanford Company

C. J. Alderman

N1-21

D. W. Bergmann

R3-86

A. E. Bridges

L5-01

B. S. Carlisle

X3-71

S. A. Chastain

L5-01

R. G. Cowan

R3-86

J. I. Dearing

$\mathrm{N} 1-32$

B. B. Emory

$\times 3-70$

J. C. Fulton

R3-85

J. R. Frederickson

R3-86

E. W. Gerber

R3-86

S. L. Hecht

L5-01

G. A. Last

L. A. Lawrence

R. D. Leggett

(5)

L5-01

B. J. Makenas

L5-01

R. L. McCormack

L5-01

C. T. Miller II

L5-01

G. C. Mooers

R3-86

F. W. Moore

$\mathrm{X} 3-72$

R. P. Omberg (2)

R3-85

J. Perez-Carter

$\mathrm{N} 1-25$

R3-86

A. L. Pitner

L5-01

J. P. Schmidt

L5-0I

D. W. Smith

$\times 3-73$

C. A. Thompson

R3-85

D. J. Trimble

X3-72

J. E. Truax

L5-01

J. W. Weber

X3-71

M. J. Wiemers

L5-01

D. R. Wilson

R3-86

J. C. Womack

L5-01

OSTI (2)

R3-85

L8-07

Central Files

L8-04 